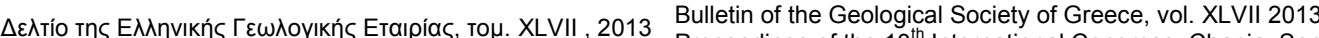
XLVII , 2013 Proceedings of the $13^{\text {th }}$ International Congress, Chania Sept.

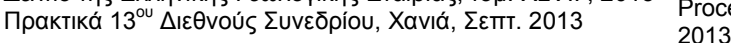

\title{
MORPHOTECTONIC ANALYSIS OF FAULTS IN SPERCHIOS BASIN (FTHIOTIS, CENTRAL GREECE)
}

\author{
Michail M. ${ }^{1}$ and Chatzipetros A. ${ }^{1}$ \\ ${ }^{1}$ Aristotle University, Department of Geology, 54124, Thessaloniki, Greece \\ mariamichail@geo.auth.gr,ac@geo.auth.gr
}

\begin{abstract}
This paper aims to study one of the major neotectonic, fault-controlled, features of the Hellenides, Sperchios basin, with the application of specific morphotectonic indices. The study area includes well exposed fault-bounded mountain fronts with dominant footwall relief. The most prominent structures of this WNW-ESE trending neotectonic basin are WNW-ESE to NW-SE trending faults, the most prominent of which is the Sperchios Fault System (SFS) causing mainly subsidence toward the NNE. The antithetic Coastal Fault System (CFS) also forms a distinct, yet gentler relief at the NE basin boundary. The segmentation of these neotectonic faults allowed detailed measurements, based on morphotectonic characteristics, of each segment separately. Mountain-front sinuosity $\left(S_{m f}\right)$ as well as the ratio of valley floor width to valley height $\left(V_{f}\right)$ were among the indices used in this study and contributed to the identification of the potential fault activity. The results show that there is a strong correlation between uplift rates and the morphotectonic signature of faulting, as well as a clear morphotectonic differentiation of fault segments.
\end{abstract}

Key words: segmentation, morphotectonic indices, Sperchios basin, central Greece, active tectonics

\section{Пєрі́ $\eta \psi \eta$}

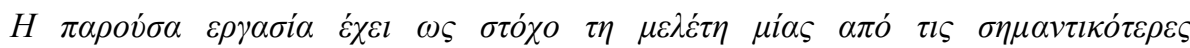

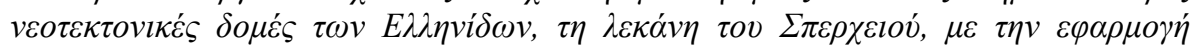

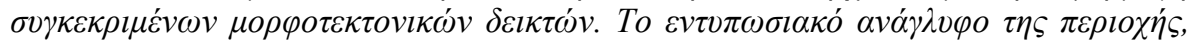

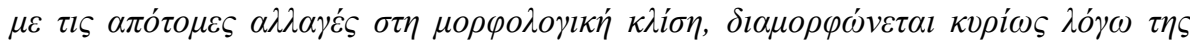

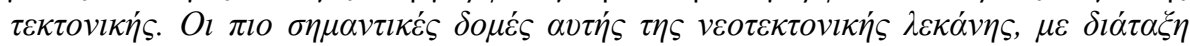

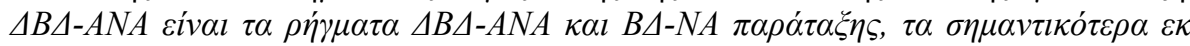

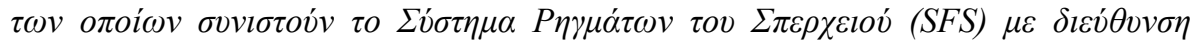

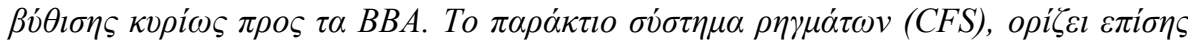

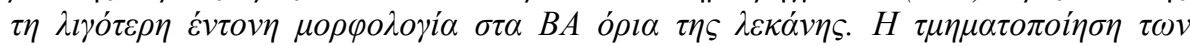

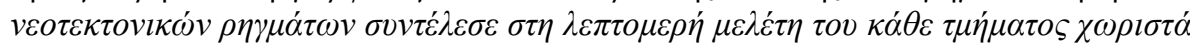

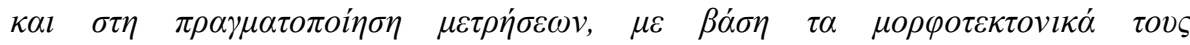

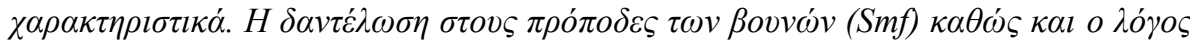

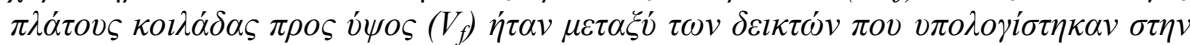

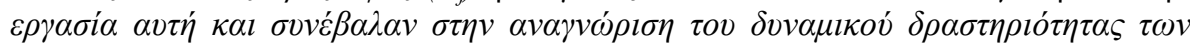

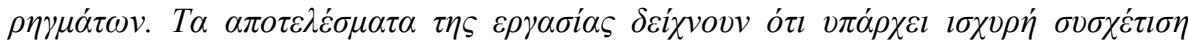

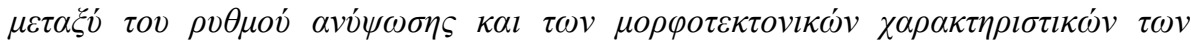




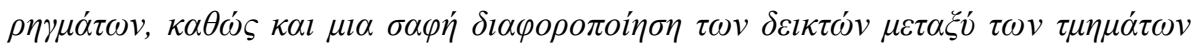
$\tau \eta \varsigma \rho \eta \xi \xi \gamma \varepsilon v o v ́ \varsigma \zeta \omega ́ v \eta \varsigma$.

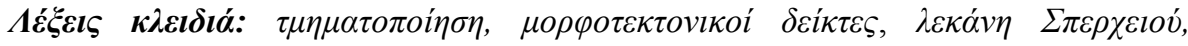

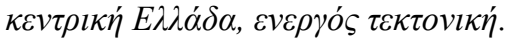

\section{Introduction - Geological Setting}

The quantitative measurement of an active tectonic landscape, as well as landform evaluation, could provide us with basic information necessary for estimating long-term deformation. Sperchios Basin is one of the most important neotectonic features of Greece, within an area where active tectonics have drastically controlled and formed the landscape. Sperchios basin is located in the Fthiotis area, East Central Greece. It has a mean WNW-ESE axis, and it extends from Mt. Tymfristos to the west, to Maliakos Gulf to the east (Kranis, 1999). The basin is defined by the mountainous areas of Timfristos to the west, Othris to the east and Kallidromo to the south. Extension has dominated the deformation of the region in the Quaternary period, starting at Late Pliocene - Early Pleistocene, continuing until today. The most important structures are the WNWESE to NW-SE trending, NNE-dipping faults that control the margins of this neotectonic basin. However, faults with ENE-WSW and/or NE-SW strike are also present. In this paper we focus on the tectonically young southern margin of Sperchios Basin, which is dominated by large normal faults of E-W to WNW-ESE strike, like most of the neotectonic structures of central Greece (Psomiadis, 2010; Tzanis et al., 2010).

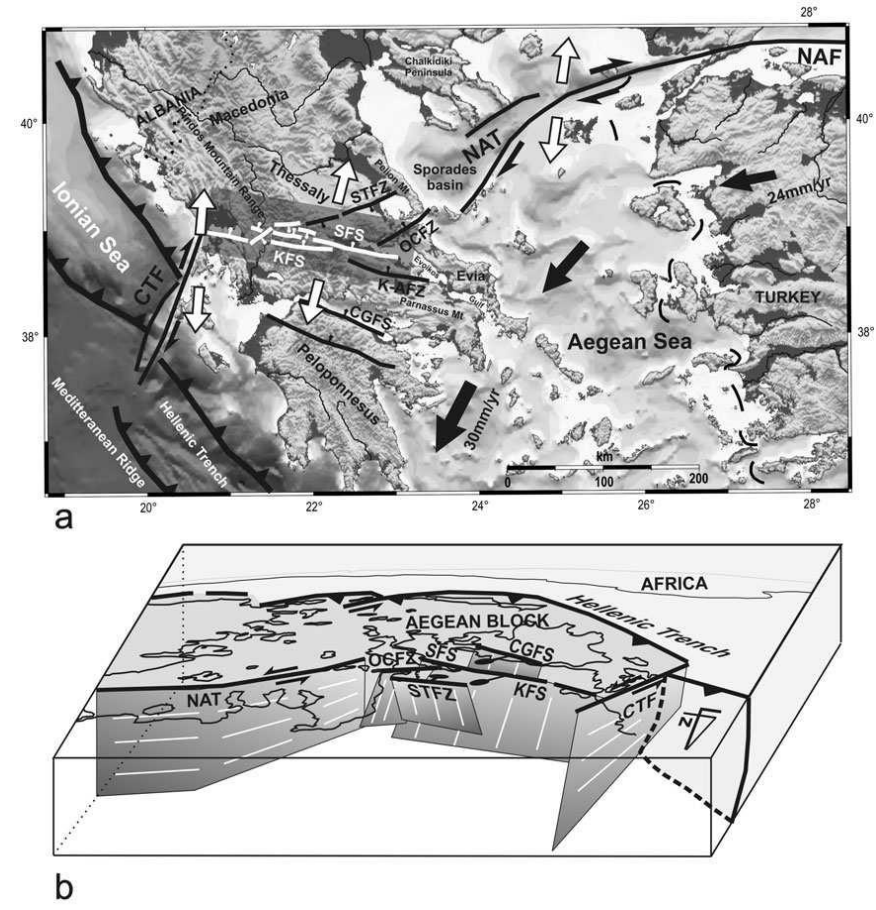

Figure 1 - (a) Generalized shaded relief map, showing the major structures that control Sperchios basin and the suggested relationship between the Sperchios Fault System (SFS) with the right-lateral North Aegean Trough (NAT), the Kefallonia Transform Fault (CTF), Kallidromo Fault System (KFS), Corinthos Golf Fault System (CGFS). The arrows indicate the different kinematics (contractional, extensional, strike-slip) and (b) 3D-tectonic sketch indicating the relationship of the KFS and SFS in Central Greece with the right lateral strike-slip CTF and NAT. The relative motion of the faults is indicated with white lines. (after Kilias et al. 2008).

XLVII, No $1-296$ 
The southern part of Sperchios basin is comprised by the Sperchios Fault System (SFS) (Figure 1, 2), which consists of two major fault segments, Sperchiada and Kompotades faults, at its western and eastern part, respectively, and the Coastal Fault System (CFS), the western part of the south coast of the North Gulf of Evia, comprising three main faults, the Arkitsa-Longos fault to the east, the Agios Konstantinos fault in the middle and the Kamena Vourla fault to the west (Ganas, 1997; Kranis, 1999) (Figure 2). In addition, it is suggested that the Sperchios Fault System (SFS), together with the Coastal Fault System (CFS), interact through an underlapping crustal relay zone, which accommodates the differential movement between the North Aegean Fault to the east and the Kefallonia Transform Fault to the west, on the western termination of the Hellenic Arc (Kilias et al., 2008). The basin includes pre-rift formations such as limestones, flysch, radiolarites, ophiolites and a volcaniclastic sequence, Neogene deposits and synrift formations of Tertiary and Quaternary age (alluvial fans) (Figure 2). Eliet \& Gawthorpe (1995) studied the sedimentary supply of Sperchios basin in relation to active tectonics and footwall uplift, as recorded mainly in the Quaternary sedimentary sequences.

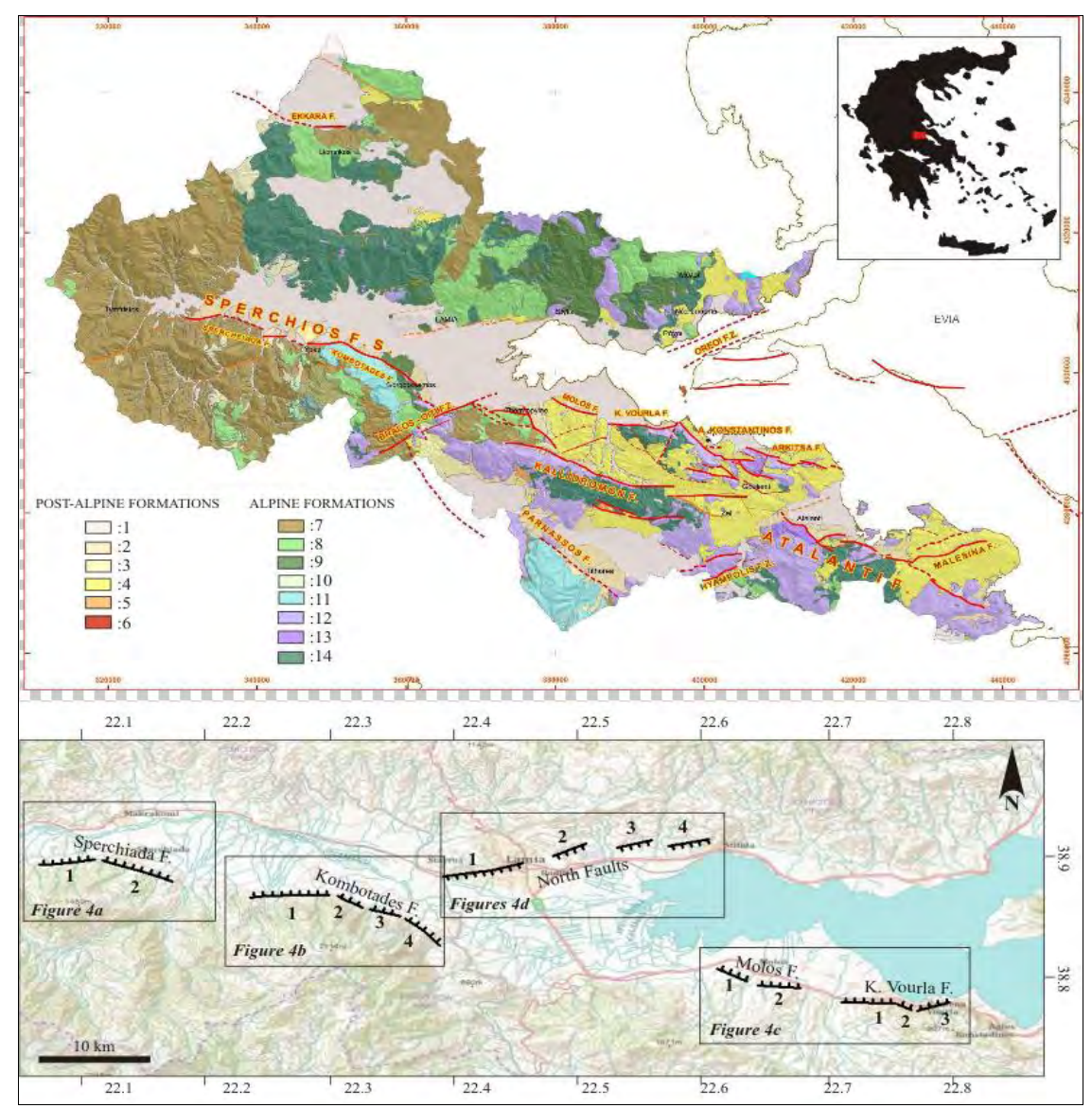

Figure 2 - Top: Geological - Neotectonic map of Fthtiotis (from Kranis, 1999). Post-Alpine formations: 1 - alluvial deposits, 2 - lateral scree, 3 - Pleistocene sediments, 4 - Neogene sediments, 5 - Molassic sediments, 6 - Quaternary volcanics (Lichades \& Ag. Konstantinos areas) Alpine formations, 7 - Flysch, 8 - Upper Cretaceous carbonates, 9 - Schist-chert formation, 10 - Pindos and Vardousia carbonates, 11 - Parnassos carbonates, 12 - sub-

Pelagonian carbonates, 13 - Volcanosedimentary complex, 14 - Ophiolites. Bottom: Topographic map indicating the faults and their segments of the current study (Sperchiada, Kompotades, Molos, Kamena Vourla and North Faults). 
Geomorphic indices have been applied to mountain ranges worldwide in order to determine the relative tectonic activity (e.g. Bull \& McFadden, 1977; Keller \& Pinter, 1996; Gawthorpe \& Leeder, 2000; Bull 2007, 2009). In this paper the faults that have been studied are the Sperchiada fault that bounds the southern part of the basin, Kompotades fault, which controls the central part of the basin, Molos and Kamena Vourla faults on the east-southern part and the North Faults, which are smaller scale faults at the northern part of the basin (Figure 2). The selection of those faults was based on the idea of collecting information from several parts of the basin (north, south, south-east, south-west), with the aim to make a general estimation of the current morphogenetic processes acting on the study area, thus to compare the tectonic activity between the different fault segments, in both southern and northern margins of the basin. The first stage was to separate the fault zones into smaller segments, based on published studies and field data (e.g. changes in the mountain front orientation, overstepping of fault strands, etc.). The second stage included the application of geomorphic indices along the segments of those neotectonic faults. The fault segmentation contributed to the general morphometric analysis of the area and the estimation of the degree of activity for each segment.

\section{Methodology}

The methodology used in this paper was based on the calculation of specific geomorphic indices, using a detailed Digital Elevation Model for the area and the characterization of fault segments in terms of activity, based on the results.

\subsection{Geomorphic Indices}

In this paper we have applied certain well-established and useful geomorphic indices associated with fluvial systems:

\section{- Transverse Topographic Symmetry (T)}

The Transverse Topographic Symmetry Factor is defined as:

$$
T=\frac{D_{a}}{D_{d}}
$$

where $D_{a}$ is the distance from the midline of the active meander belt and $D_{d}$ is the distance from the basin midline to the basin divide. For an absolutely symmetrical basin, $\mathrm{T}=0$. As long as $\mathrm{T}$ increases and approaches the 1 , the asymmetry increases. $\mathrm{T}$ is a vector, with direction and magnitude that varies from 0 to 1 . The direction of a regional migration of the main stream channel could be an indication of the ground tilting in this direction. Values of $\mathrm{T}$ are calculated for different segments of a valley and indicate preferred migration of streams perpendicular to the drainage basin axis (Keller \& Pinter, 1996). This method does not provide us with direct evidence of ground tilting, but it is an important fault activity indicator.

- Mountain front sinuosity (Smf)

Mountain front sinuosity $\left(\mathbf{S}_{\mathbf{m f}}\right)$ is defined as:

$$
S_{m f}=\frac{L_{m f}}{L_{s}}
$$

where $\mathrm{L}_{\mathrm{mf}}$ is the length of the mountain front along the foot of the mountain and $\mathrm{L}_{\mathrm{s}}$ is the straight line length of the mountain front (Bull \& McFadden, 1977; Keller \& Pinter, 1996). This indicator reflects the balance between uplift, that tends to maintain a relatively straight front, and erosion, that tends to produce irregular fronts. Mountain fronts connected with active uplift are quite straight, but if the rate of uplift is reduced, erosional processes will begin to form a sinuous front that becomes more asymmetrical with time. $\mathrm{S}_{\mathrm{mf}}$ values ranging between 1.0 and 1.6 values indicate

XLVII, No 1 - 298 
tectonically active fronts. Higher $S_{\mathrm{mf}}$ values $(>3)$ are normally associated with inactive fronts in which the initial range front fault may be more than $1 \mathrm{~km}$ away from the present erosional front (Bull \& McFadden, 1977).

\section{- Ratio of Valley-Floor Width to Valley Height (Vf)}

The ratio of the width of valley floor to valley height $\left(V_{f}\right)$ may be expressed by:

$$
V_{f}=\frac{2 \cdot V_{f w}}{\left(E_{l d}-E_{s c}\right)+\left(E_{r d}-E_{s c}\right)}
$$

where $V_{f w}$ is the width of valley floor, $E_{l d}$ and $E_{r d}$ are the elevations of the left and right valley divides respectively looking downstream and $\mathrm{E}_{\mathrm{sc}}$ is the elevation of the valley floor (Bull \& McFadden, 1977). This index reflects in this way differences between broad -floored canyons ( $U$ - shaped) with relatively high values of $V_{f}\left(V_{f}\right.$ values $\left.>1\right)$ and $V$-shaped canyons with relatively lower values of $V_{f}\left(V_{f}\right.$ values $\left.<1\right)$ (Keller, 1986). Comparison of $V_{f}$ values provide us with the information whether the streams are actively down cutting in response to active tectonics, forming V-shaped valleys, or are being eroded laterally, forming broad valleys, because of front stability and drainage.

\section{- Drainage Basin Asymmetry (AF)}

The asymmetry factor is expressed by:

$$
A F=100 \cdot \frac{A_{r}}{A_{f}}
$$

where $A_{r}$ is the area of the basin to the right (facing downstream) of the main stream and $A_{t}$ is the total area of the drainage basin (Cox, 1994). In the area where drainage develops together with active tectonic deformation, the network tends to have a specific geometry. If the stream network continues to flow in a stable setting, AF should be almost equal to value 50. Values of AF greater or less than 50 infer "Tilting" to the left or to the right respectively.

\subsection{Fault Segmentation}

Fault segmentation is applied to different long faults around the world. The theories imply that faults initiate as separate faults, propagate, and ultimately link to form a long fault (e.g. Ganas \& Papoulia, 2000). In order to achieve a better result in our study, we segmented the following faults into smaller sections, taking into consideration the changes in the mountain front orientation and the morphology along the faults.

\section{- Sperchiada Fault (Figure 3a) and Kompotades Fault (Figure 3b)}

Sperchiada fault to the west and Kompotades fault to the east are the two major segments of Sperchios Fault System, which control the southern margin of the Sperchios basin and have a total length of almost $80 \mathrm{~km}$. We have distinguished two segments for the Sperchiada fault and four segments for the Kompotades Fault. The strike of those faults is E-W to WNW-ESE, while they dip to the NNE. The main criterion for distinguishing smaller segments is the small change in their orientation. This does not necessarily reflect their actual structural segmentation, but there is definitely a geomorphic segmentation that corresponds to different geomorphic quantification.

\section{- Molos Fault (Figure 3c) and Kamena Vourla Fault (Figure 3c)}

Molos and Kamena Vourla Faults are dipping to the NNW. Molos is a probable westward extension of the Coastal Fault System which controls the western part of southern coast of the North Gulf of Evia (Ganas, 1997). It is characterised by NW-SE strike and we have segmented it into two parts. Kamena Vourla fault, at the west part of the Coastal Fault System, is a high angle structure with an E-W strike. 


\section{- North Fault zone (Figure 3d)}

The last fault zone tested in this paper is the North Fault zone. In contrast with the previously mentioned faults, North Fault zone controls the northern margin of Sperchios basin. It is approximately $10 \mathrm{~km}$ long with fault striking NE-SW and dipping to the SE. Four segments are proposed for the North Fault zone.

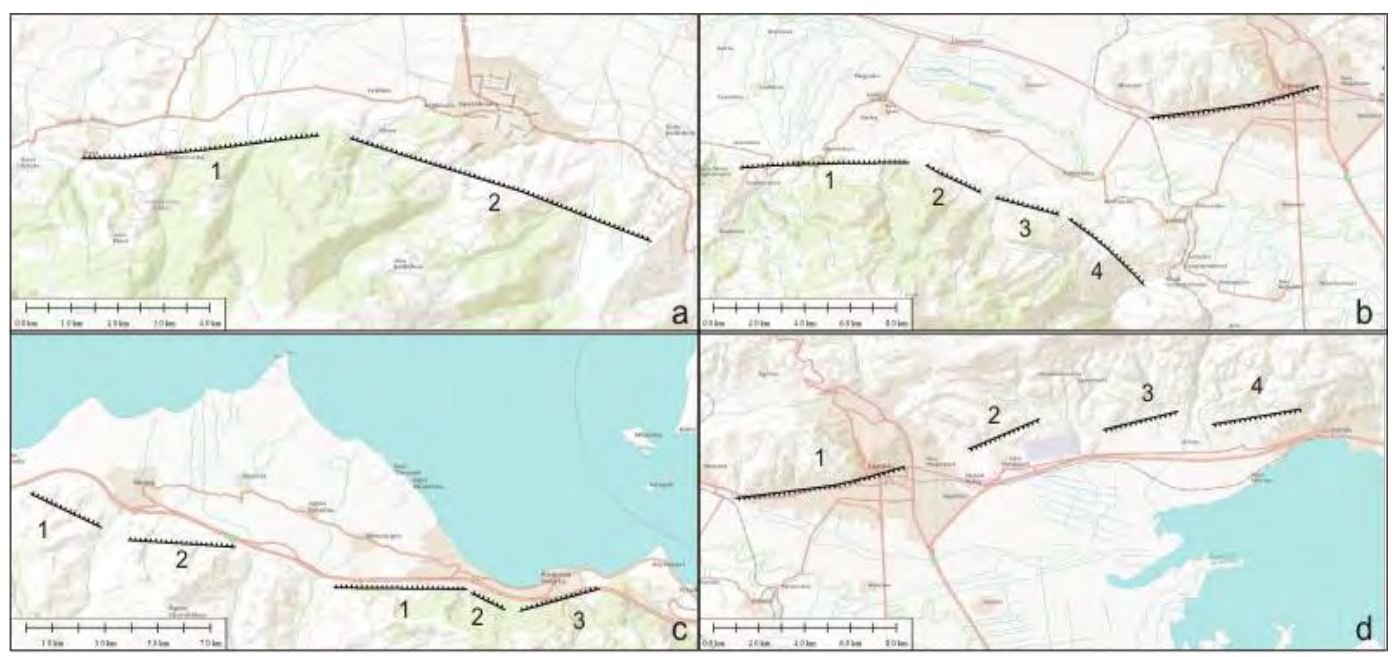

Figure 3 - Segmentation of the studied faults. (a) Sperchiada F. divided into two segments (b) Kompotades F. divided into four segments (c) Molos (two segments) and Kamena Vourla F. (three segments), (d) North Fault (four segments).

\section{Data}

The morphometric analysis in this paper is based on the application of geomorphic indices derived from a Digital Elevation Model (DEM) of the broader area. The work comprised of collection of published geological maps (IGME 1967, 1970), information based on publications, processing and evaluation of data and finally implementing the principal morphotectonic indicators on the fault segments by using Global Mapper 12 software. The data source was Aster GDEM, Worldwide Elevation Data (1.5 arc-second resolution) and the projection used was Greek Grid (GGRS87).

\subsection{Tilting of Sperchios Basin}

Two indices have been applied in order evaluate the Sperchios Basin asymmetry: Transverse Topographic Symmetry, T (Figure 4), and Drainage Basin Asymmetry, AF (Figure 5). In order to calculate the $\mathrm{T}$ index, the basin midline of Sperchios River was determined in the middle with a red line (Figure 4). Along this midline we have separated 13 equal 4-km long segments. Based on the results shown in the table of Figure 4, it is evident that $\mathrm{T}$ factor at the first segment as well as between sites $\mathrm{p} 8$ and $\mathrm{p} 10$, has the highest values, ranging from 0,35 to 0,45 , suggesting that the asymmetry at the beginning and in the centre of the basin increases, in comparison to the other segments. Figure 4 shows the drainage basin asymmetry of Sperchios Basin. The area enclosed within the yellow line, along the watershed, is the total area of the basin. The red shaded area is the area to the right (facing downstream) of the main stream of Sperchios (blue). The asymmetry factor in Sperchios Basin has a value of 55, showing that the basin has a tectonic rotation (tilting) to the North. One would expect that the basin would show tilt towards the South, where the main fault zone is. However this is not the case for this basin. Our interpretation is that Sperchios fault zone produced a great footwall uplift, causing extensive erosion and hence formation of very big alluvial fans, e.g. the huge Vamvakia alluvial fan at the central part of the basin. These fans have 
shifted the position of Sperchios River towards the North, overprinting the tectonic signature of Sperchios fault.

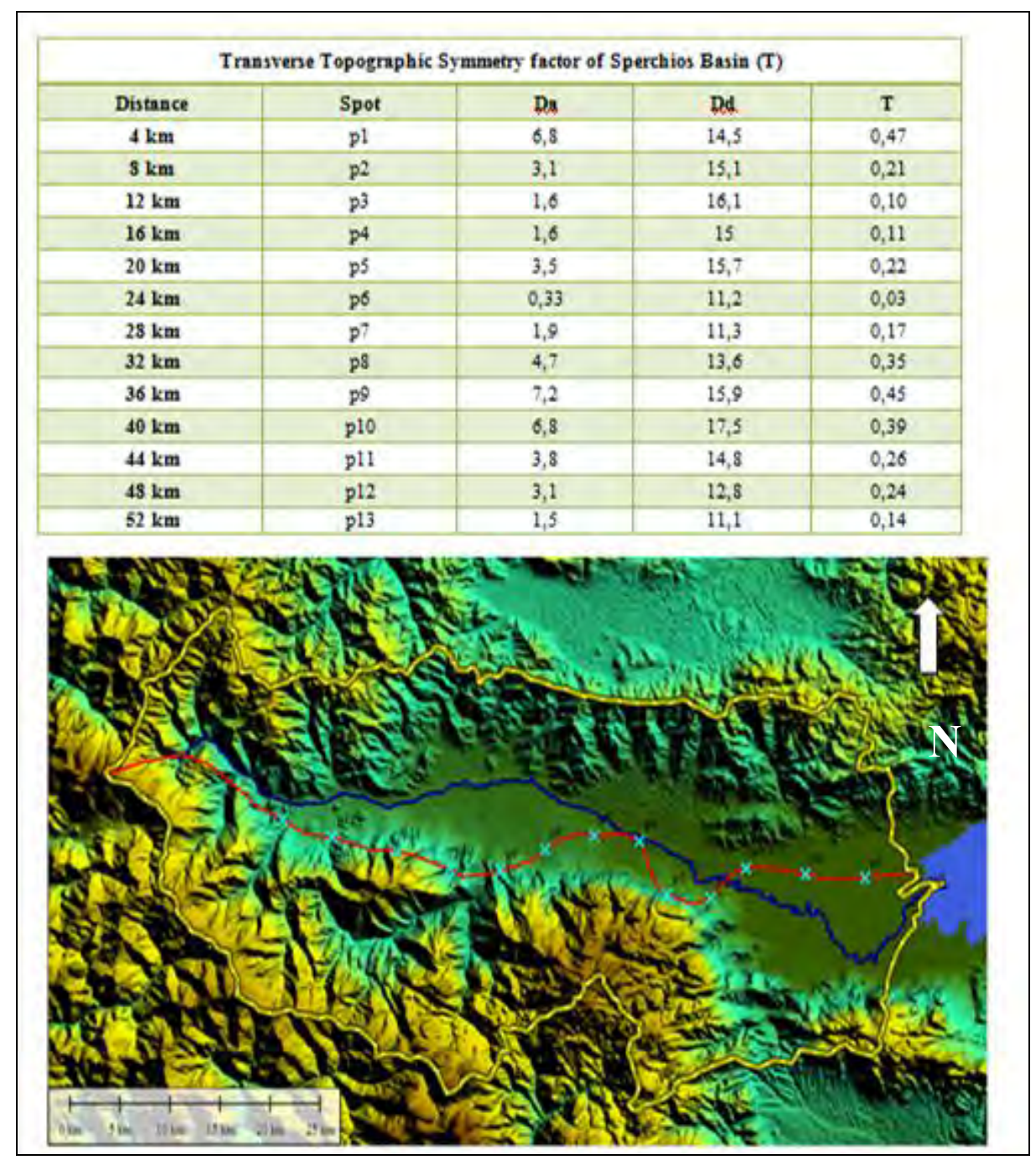

Figure 4 - (a) Table with the results of Transverse Topographic Symmetry (T) along the whole Sperchios Basin. (b)View from Global mapper, showing the 4-km long segments (p1, p2, ..., p13) separated by a light blue x symbol, along basin midline, blue line: main river, red line: basin midline, yellow line: Sperchios basin watershed.

\section{2. $S_{m f}$ and $V_{f}$ values for Sperchios, Kompotades, Molos, Kamena Vourla and North Faults}

The application of $S_{m f}$ and $V_{f}$ geomorphic indices along the segments of the these faults can contribute towards a comprehensive overview of the neotectonic activity. The $\mathrm{V}_{\mathrm{f}}$ values are plotted with the $\mathrm{S}_{\mathrm{mf}}$ values on a same diagram. This combination provides quantitative information of the relative degree of tectonic activity classes of the segmented faults and allows individual mountain fronts to be assigned in different tectonic activity classes (Bull \& McFadden, 1977; Keller \& Pinter, 1996). The $S_{m f}$ and the mean $V_{f}$ values of all the segmented faults in our study, are shown in the $\mathrm{S}_{\mathrm{mf}} \mathrm{vs}$. $\mathrm{V}_{\mathrm{f}}$ diagrams (Figure $6 \mathrm{a}, \mathrm{b}, \mathrm{c}$ ). 


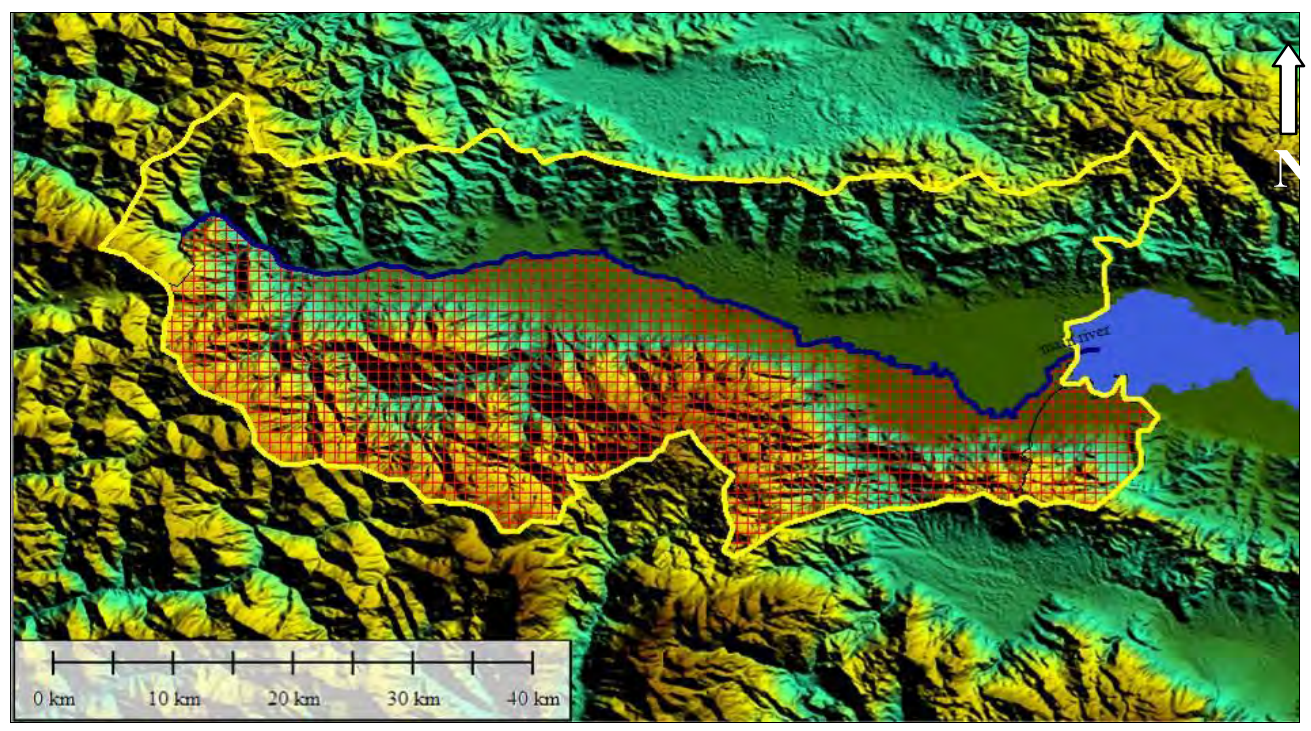

Figure 5 - Drainage Basin Asymmetry (AF). Red area: $A_{r}$, the area of the basin to the right (facing downstream) of the main stream, area within yellow line: $A_{t}$, the total area of the drainage basin. $A_{t}: 1,830 \mathrm{~km}^{2}, A_{r}: 1,015 \mathrm{~km}^{2}$.
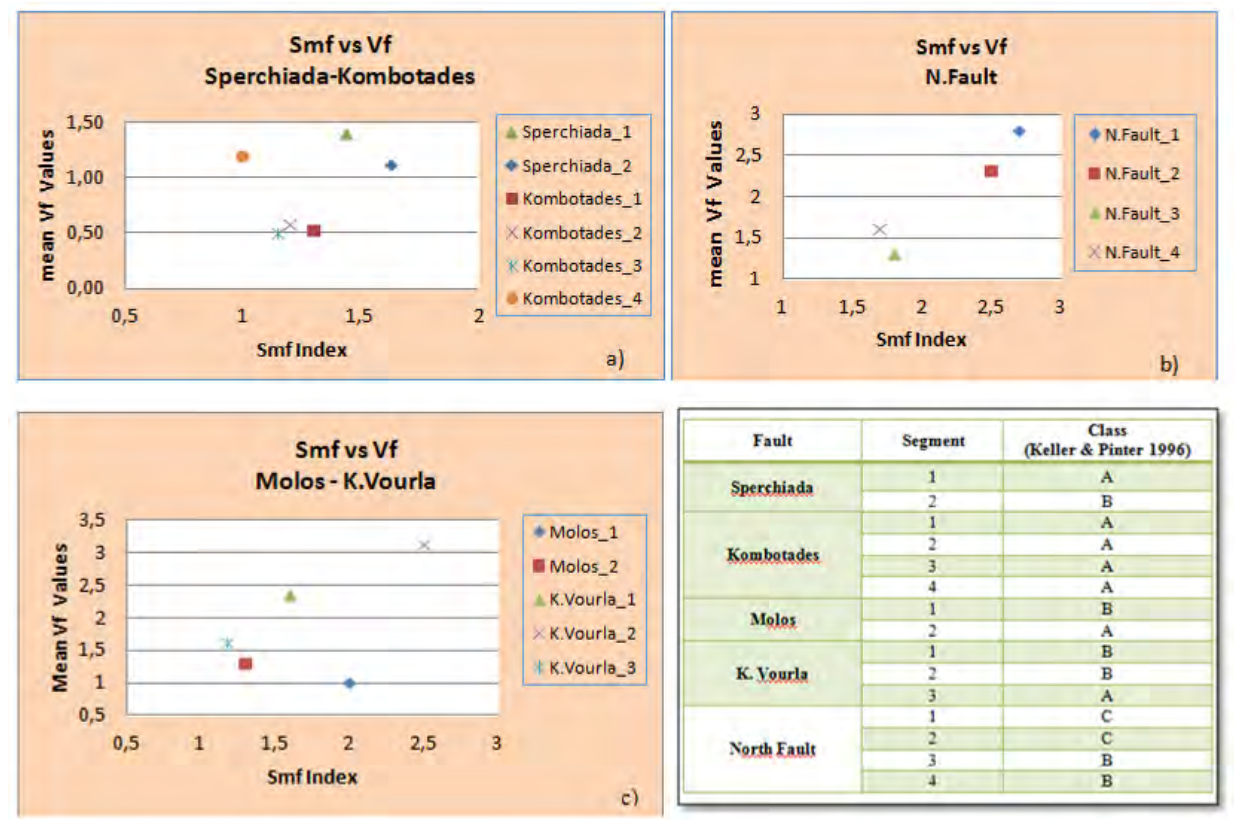

Figure 6 - Plot of mean $S_{m f}$ and $V_{f}$ values of all the segmented faults of this study (a) Sperchiada and Kompotades faults, (b) North faults, (c) Molos and Kamena Vourla faults. Table: Classification of segments of each fault separately, according to the tectonic class division by Keller \& Pinter (1996).

According to the active tectonic classification suggested by Keller \& Pinter (1996), each fault segment appears to have a different activity, regardless their position or the fact that some of them even belong to the same Fault. The first (A) tectonic class comprises values of $\mathrm{S}_{\mathrm{mf}}$ lower than 1.5 
and $\mathrm{V}_{\mathrm{f}}$ values lower than 1.2. The second class consists of $\mathrm{S}_{\mathrm{mf}}$ lower than 2.5 and $\mathrm{V}_{\mathrm{f}}$ lower than 1.5 and the third class is characterized by $\mathrm{S}_{\mathrm{mf}}$ higher than 2.6.

The two segments of Sperchiada Fault are of tectonic class A and B, for the western and eastern part respectively. In addition, for the Kompotades fault case its eastern part has lower $\mathbf{S}_{\mathrm{mf}}$ values related to its western part, however all of the segments belong to the A class, which characterizes the more active faults. The results are in good agreement with Zovoili et al. (2004). Moreover, Molos fault, is separated into two different segments which show a different activity, with the western part (Molos_1) less active than the eastern. Three segments have been distinguished for Kamena Vourla fault. All of them reveal an active behaviour with the eastern segment (K.Vourla 3) showing higher activity (class A). Finally, North faults seem to have a lower activity in comparison with the southern marginal large faults.

\section{Conclusions}

The aim of this paper was to make a general estimation of the neotectonic signature of faulting to the relief in Sperchios basin and to compare the tectonic activity between the different fault segments, in both southern and northern margins of the basin. The application of the geomorphic indices associated with fluvial systems $\left(\mathrm{T}, \mathrm{AF}, \mathrm{S}_{\mathrm{mf}}, \mathrm{V}_{\mathrm{f}}\right)$ on Sperchios basin and Sperchiada, Kompotades, Molos, Kamena Vourla and North faults, helped in correlating the current landscape form with the neotectonic evolution of the area. Based on the combination of the derived geomorphic indices, Sperchios Basin appears to have a tectonic tilting (high T values in the centre of the basin) to the North ( $\mathrm{AF}=55$ ). After having all the above faults classified based on their $\mathrm{S}_{\mathrm{mf}}$ and $\mathrm{V}_{\mathrm{F}}$ values, we suggest that North Faults appear to be less active (B to $\mathrm{C}$ class) in comparison with all the others (A to B class). In addition we observed that even along the same fault the segments seem to have a different tectonic activity.

In respect to segmentation, quantitative morphotectonic analysis can provide valuable information, complementary to structural criteria in order to segment a fault zone. In Sperchios basin the morphotectonic segmentation is in good agreement with the segmentation derived from mapping and structural analysis. It has to be noted however that quantitative morphotectonic analysis can only provide indications, not evidence of recent tectonic activity. It is therefore important to extend the deformation record of Sperchios fault zone by geological methods (i.e. paleoseismology), in order to enhance the morphotectonic observations.

\section{Acknowledgements}

The authors would like to thank reviewers Drs. A. Ganas and S. Kokkalas, for their critical and helpful comments, which led to substantial improvement of this paper. The second author has been partly supported by the project "Characterization of site conditions in Greece for realistic seismic ground motion simulations: pilot application in urban areas", a THALES programme project, funded by the General Secretariat for Research and Technology of Greece.

\section{References}

Bull W. and McFadden L. 1977. Tectonic geomorphology north and south of the Garlock Fault, California, Geomorphology in Arid regions, D.O., Doehring, ed., Publications in Geomorphology, State University of New York at Bingamton, 115-138.

Bull W. 2007. Tectonic geomorphology of mountains: a new approach to paleoseismology. WileyBlackwell; 1 edition.

Bull W. 2009. Tectonically Active Landscapes. Wiley-Blackwell; 1 edition.

Cox R.T. 1994. Analysis of drainage basin symmetry as a rapid technique to identify areas of possible quaternary tilt block tectonics: an example from the Mississippi embayment, Geol. Soc. Am. Bull., 106, 571 - 581.

XLVII, No $1-303$ 
Eliet P.P.and Gawthorpe R.L. 1995. Drainage development and sediment supply within rifts, examples from the Sperchios Basin, central Greece, Journal of the Geological Society of London, 152, Part 5, 883-893.

Ganas A. 1997. Fault segmentation and seismic hazard assessment in the Gulf of Evia Rift, central Greece. Unpublished PhD thesis, University of Reading, 369 pp.

Ganas A. and Papoulia I., 2000. High-resolution, digital mapping of the seismic hazard within the Gulf of Evia Rift, Central Greece using normal fault segments as line sources, Nat. Hazards, 22(3), 203-223.

Gawthorpe R.L. and Leeder M.R. 2000. Tectono-sedimentary evolution of active extensional basins, Basin Research, 12, 195-218

IGME 1967. Geological map of Greece, scale 1:50,000, Lamia sheet. Institute of Geology and Mineral Exploration, Athens.

IGME, 1970. Geological map of Greece, 1:50,000, Sperchias sheet, Institute of Geology and Mineral Exploration, Athens.

Keller A.E.and Pinter N. 1996. Active Tectonics: Earthquakes, Uplift and Landscape, Prentice Hall, $338 \mathrm{p}$.

Keller E. 1986. Investigation of active tectonics: use of surficial earth processes. In: Wallace, R.E. (Ed.), Active Tectonics. Studies in Geophysics. Nat. Acad. Press, Washington, DC, p136147.

Kilias A., Tranos M., Papadimitriou E., Karakostas V., 2008. The recent crustal deformation of the Hellenic orogen in Central Greece; the Kremasta and Sperchios Fault Systems and their relationship with the adjacent large structural features, Z. dt. Ges. Geowiss., 159/3, 533-547.

Kranis H.D. 1999. Neotectonic activity of fault zones in central-eastern mainland Greece (Lokris). Ph.D. Thesis.

Psomiadis E. 2010. Research of geomorphological and environmental changes in the Sperchios River Basin utilizing new technologies, Ph.D. Thesis.

Tzanis E., Kranis H. and Chailas S. 2010. An investigation of the active tectonics in central Greece with imaging and decomposition of topographic data, Journal of Geodynamics, 49, 55-67.

Zovoili E., Konstantinidi E. and Koukouvelas I.K. 2004. Tectonic geomorphology of escarpments: the cases of Kompotades and Nea Anchialos faults, Bulletin of the Geological Society of Greece, 36, 1716-1725. 